WOJCIECH CHODOROWICZ1

\title{
Zobowiązanie do leczenia osób uzależnionych od alkoholu
}

Jeśli chodzi o zasadę, podjęcie leczenia i terapii w Polsce jest dobrowolne. Wyjątki od tego ustalenia muszą być regulowane ustawą. Stosowanie przepisów dotyczących przymusowego leczenia bądź terapii powinno następować z uwzględnieniem konstytucyjnych gwarancji praw i wolności obywatelskich. Pojęcie przymusu leczenia ma charakter wielopłaszczyznowy. Przy jego stosowaniu uwzględnia się interes zdrowotny zbiorowości, samego pacjenta, przeważający interes osób trzecich (np. członków najbliższej rodziny itp.) bądź interes wymiaru sprawiedliwości. Należy stwierdzić, iż nie jest ono jednoznaczne - dlatego też dla wyjaśnienia winno się uporządkować to, co składa się na jego desygnat, oraz wprowadzić pewną dyscyplinę terminologiczną. Przymus leczenia (pośredni i bezpośredni) możemy rozumieć sensu stricto jako taki, który jest oparty na ustawie, a także sensu largo - jako obowiązek poddania się leczeniu bądź terapii.

Przedmiotem moich rozważań jest przedstawienie aktualnych polskich regulacji prawnych dotyczących przymusu leczenia i terapii osób uzależnionych od alkoholu. Nie wchodząc w szczegóły, należy

1 Ur. 1968 r. Absolwent Wydziału Nauk Społecznych, Instytut Psychologii oraz Prawa i Administracji Uniwersytetu Cdańskiego. Doktorant Wydziału Prawa i Administracji U] i Wydziału Teologii UPJP II. Biegły przez 2 kadencje Sądu Okręgowego w Cdańsku. 
nadmienić, iż uzależnienie polega na niezdolności do kontrolowania ilości przyjmowanej substancji chemicznej, np. alkoholu² ${ }^{2}$ Jest stanem fizycznym i psychicznym wynikającym z interakcji między organizmem a substancją psychoaktywną (alkohol, narkotyki, nikotyna, leki itp.), charakteryzującym się zmianami w zachowaniu lub innymi reakcjami (np. przymus przyjmowania danej substancji w sposób ciągły lub okresowy w celu doświadczenia jej wpływu na psychikę czy uniknięcia przykrych objawów odstawienia itp.).

W aktualnym polskim stanie prawnym przymus leczenia uzależnienia od alkoholu regulują m.in.:

- ustawa z dnia 26 października 1982 roku o wychowaniu w trzeźwości i przeciwdziałaniu alkoholizmowi [dalej: UoWwTiPA] ${ }^{3}$;

- ustawa z dnia 19 sierpnia 1994 roku o ochronie zdrowia psychicznego [dalej: UoOZP] ${ }^{4}$;

- ustawa z dnia 6 czerwca 1997 roku. Kodeks karny ${ }^{5}$.

Ustawa z dnia 26 października 1982 roku o wychowaniu w trzeźwości i przeciwdziałaniu alkoholizmowi w zakresie lecznictwa odwykowego osób uzależnionych od alkoholu różni się od poprzednio obowiązującej ustawy z dnia 10 grudnia 1959 roku o zwalczaniu alkoholizmu ${ }^{6}$. W szczególności ustawa z 1959 roku uwypuklała przymus leczenia alkoholików w zakładach lecznictwa otwartego i zamkniętego, natomiast ta z 1982 roku jako zasadę leczenia odwykowego przyjmuje jego dobrowolność, stwarzając równocześnie warunki sprzyjające realizacji go $^{7}$. Za podstawę

2 Por. D. Semple i in., Oksfordzki podręcznik psychiatrii, red. nauk. pol. wyd. A. Grzywa, Lublin 2007, s. 106-107.

3 Dz.U. 1982.35.230 z późn. zm.

4 Dz.U.1994.111.535 z późn. zm.

5 Dz.U. 1997.88.553 z późn. zm.

6 Dz.U. 1997.88.553 z późn. zm.

7 Por. uchwała Sądu Najwyższego [dalej: SN] z dnia 22 czerwca 1984 r., III CZP 17/84, Lex Omega 3000, Orzecznictwo Sądu Najwyższego. Izba Cywilna [dalej: OSNC], 1984/12/208. 
powyższego uregulowania ustawodawca przyjął aktualny stan wiedzy i dotychczasowe doświadczenia leczenia odwykowego, które potwierdzały, że dobrowolne leczenie daje większe szanse jego skuteczności.

Orzeczenie o przymusowej terapii osoby uzależnionej od alkoholu stanowi przejaw ograniczenia wolności. Godzi zatem w jedno $\mathrm{z}$ podstawowych praw obywatelskich. Osoba uzależniona ma prawo do wolności osobistej i ochrony własnej godności, co gwarantuje jej art. 30 i 31 Konstytucji Rzeczypospolitej Polskiej ${ }^{8}$ oraz art. 10 Konwencji o ochronie praw człowieka i podstawowych wolności ${ }^{9}$. Zgodność z Konstytucją przepisów o przymusowej terapii osób uzależnionych od alkoholu stwierdził Trybunał Konstytucyjny w wyroku z dnia 4 lipca 2006 roku $^{10}$, stwierdzając jednocześnie, że interwencja władzy publicznej w sposób życia osoby uzależnionej jest podyktowana tylko ochroną bezpieczeństwa i porządku publicznego oraz praw i wolności innych osób ${ }^{11}$. Dlatego postępowanie $\mathrm{w}$ przedmiocie przymusowego leczenia winno być przeprowadzane szczególnie wnikliwie na każdym jego etapie ${ }^{12}$. Zwracał na to uwage Sąd Najwyższy już na gruncie poprzednio obowiązującej ustawy Z 1959 roku $^{13}$.

Konwencja o ochronie praw człowieka i podstawowych wolności sporządzona w Rzymie dnia 4 listopada 1950 r., zmieniona następnie Protokołami nr 3, 5 i 8 oraz uzupełniona Protokołem nr 2 (Dz.U. 1993.61/284).

10 K 43/05, Orzecznictwo Trybunału Konstytucyjnego. Zbiór Urzędowy. Seria A [dalej: OTK-A], 2006/7/78.

11 Por. postanowienie SN z dnia 9 listopada 2007 r., V CSK 241/07, LEX nr 361289, Orzecznictwo Sądu Najwyższego. Izba Cywilna. Zbiór Dodatkowy [dalej: OSNC-ZD], 2009/1/1, Biuletyn Sądu Najwyższego [dalej: Biul. SN], 2008/3/8.

12 Postanowienie SN z dnia 28 listopada 2012 r., III CSK 17/12, LEX 1293962.

13 Postanowienie z dnia 6 listopada 1963 r., III CR 268/63, Orzecznictwo Sądu Najwyższego. Izba Cywilna/Pracy, 1964/12/259. 


\section{Ustawowe działania organów państwa na rzecz osób uzależnionych od alkoholu}

W preambule ustawy o wychowaniu w trzeźwości i przeciwdziałaniu alkoholizmowi czytamy, iż prawodawca uznaje życie obywateli w trzeźwości za niezbędny warunek moralnego i materialnego dobra narodu. Dlatego też organy administracji zarówno rządowej, jak i samorządu terytorialnego są zobowiązane do inicjowania różnorodnych działań w tym zakresie. W ich polityce społecznej muszą znajdować się m.in. leczenie, rehabilitacja i reintegracja ${ }^{14}$ osób uzależnionych od alkoholu. We wspomnianej ustawie art. 1 ust. 3 obliguje te organy do współdziałania „z Kościołem Katolickim i innymi kościołami oraz związkami wyznaniowymi w zakresie wychowania w trzeźwości i przeciwdziałania alkoholizmowi”.

Na szczeblu centralnym działania na rzecz profilaktyki i rozwiązywania problemów alkoholowych w Polsce koordynuje Państwowa Agencja Rozwiązywania Problemów Alkoholowych, która podlega ministrowi zdrowia. Do jej zadań należy m.in. koordynacja i inicjowanie działań zwiększających skuteczność i dostępność lecznictwa odwykowego ${ }^{15}$.

Samorząd województwa w strategii wojewódzkiej w zakresie polityki społecznej winien opracować i wdrażać programy profilaktyki i rozwiązywania problemów alkoholowych, obejmujące m.in. leczenie i terapię osób uzależnionych. Środki na te cele powinny być uwzględnione w budżecie województwa ${ }^{16}$.

W każdym województwie zostały powołane Wojewódzkie Ośrodki Terapii Uzależnienia od Alkoholu i Współuzależnienia [dalej:

Reintegracja zawodowa i społeczna w rozumieniu przepisów o zatrudnieniu socjalnym (art. 2.1 ust. 1 pkt 10 ustawy o wychowaniu w trzeźwości i przeciwdziałaniu alkoholizmowi [dalej: UoWwTiPA]. 
WOTUW], które oprócz terapii i leczenia udzielają konsultacji specjalistycznych dla zakładów lecznictwa odwykowego na terenie województwa, koordynują pracę wojewódzkich zakładów lecznictwa odwykowego, prowadzą działalność metodyczno-organizacyjną w zakresie zbierania i opracowywania danych statystycznych dotyczących rozpowszechnienia uzależnienia od alkoholu i związanych z nim problemów oraz lecznictwa odwykowego na terenie województwa, a także oceniają uzyskane dane, inicjują i prowadzą działania podnoszące kwalifikacje zawodowe pracowników merytorycznych zatrudnionych w lecznictwie odwykowym i osób współdziałających z zakładami lecznictwa odwykowego w realizacji zadań programowych, w tym organizują staże i szkolenia. Poziom realizacji wskazanych zadań jest bardzo różny w poszczególnych województwach. Niewątpliwie zależy on m.in. od organizacyjnej i finansowej samodzielności WOTUW-ów jako zakładów opieki zdrowotnej, od poziomu finansowania działań pozaleczniczych przez WOTUW-y z puli środków urzędów marszałkowskich oraz od aktywności i zaangażowania ich kierowników w poszczególne działania na rzecz lecznictwa odwykowego w województwie.

Do zadań własnych gminy należy m.in. „prowadzenie działań związanych z profilaktyką i rozwiązywaniem problemów alkoholowych oraz integracji społecznej osób uzależnionych od alkoholu"17, w szczególności zaś „Zwiększenie dostępności pomocy terapeutycznej i rehabilitacyjnej dla osób uzależnionych od alkoholu"18.

Ustawa o wychowaniu w trzeźwości i przeciwdziałaniu alkoholizmowi nakłada na prezydentów miast, burmistrzów i wójtów obowiązek powołania komisji rozwiązywania problemów alkoholowych, których zadaniem jest m.in. prowadzenie postępowań zmierzających do orzeczenia o zastosowaniu wobec osoby uzależnionej od alkoho-

17 Art. 4.1 ust. 1.

18 Art. 4.1 ust. 1 pkt 1. 
lu obowiązku poddania się leczeniu w specjalistycznym zakładzie lecznictwa odwykowego ${ }^{19}$. Udzielają one również pomocy psychologicznej i prawnej zarówno osobom uzależnionym, jak i ich najbliższym, w szczególności tym doświadczającym przemocy w rodzinie. Zobowiązane są także do prowadzenia profilaktycznej działalności informacyjno-edukacyjnej w zakresie rozwiązywania problemów alkoholowych, zwłaszcza dla dzieci i młodzieży.

\section{Przymusowe leczenie odwykowe}

a) w trybie ustawy o wychowaniu w trzeźwości i przeciwdziałaniu alkoholizmowi

Zgodnie z treścią art. 21 ust. 2 ustawy o wychowaniu w trzeźwości i przeciwdziałaniu alkoholizmowi poddanie się leczeniu odwykowe$\mathrm{mu}$ jest dobrowolne. Ustawodawca jednak w art. 24-36 podaje wyjątki od tej zasady.

Przesłankami do zastosowania wobec osoby nadużywającej alkoholu przymusowego leczenia i terapii są m.in.: powodowanie przez nią rozkładu życia rodzinnego (np. utrata więzi uczuciowej, a także gospodarczej rodziny), demoralizacja małoletnich (czyli takie oddziaływanie na sferę psychiki, które powoduje negatywne odniesienie do wzorów postępowania i ideałów osobowych uważanych za właściwe w społeczeństwie ${ }^{20}$, uchylanie się od pracy (niepodejmowanie jej bez uzasadnionej przyczyny) oraz systematyczne zakłócanie spokoju lub porządku publicznego ${ }^{21}$. W doktrynie dominują poglądy głoszące, że przymusowemu leczeniu odwykowemu winny być poddane tylko osoby, u których uzależnienie przyczynia się do rozkładu życia rodzinnego, a w szczególności

19

20

21

Art. 4.1 ust. 1 pkt 3.

Osoba, która nie ukończyła 17 lat.

Art. 24. 
wtedy, gdy zagrożone jest dobro małoletnich dzieci ${ }^{22}$. Sąd Najwyższy $^{23}$ stoi na stanowisku, iż

nie może ulec wątpliwości, że ingerencja w sferę wolności osobistej, oparta na orzeczeniu sądowym wydanym w trybie i na podstawie art. 26 i 29 ustawy o wychowaniu w trzeźwości, służy przede wszystkim dobru osoby uzależnionej od alkoholu, a dopiero pośrednio - dobru rodziny, środowiska i Narodu ${ }^{24}$.

Postępowanie w sprawie przymusowego leczenia osoby uzależnionej od alkoholu rozpoczyna się od wydania postanowienia o skierowaniu jej na badania przez uprawnionych do orzekania o uzależnieniu biegłych, tj. psychiatrę i psychologa ${ }^{25}$. Uprawnionym do skierowania na badanie $\mathrm{w}$ przedmiocie uzależnienia w początkowej fazie jest właściwa miejscowo ${ }^{26}$ komisja rozwiązywania problemów alkoholowych ${ }^{27}$ i prokurator ${ }^{28}$, a w fazie jurysdykcyjnej właściwy miejscowo sąd. Skierowanie na badanie przez gminną komisję rozwiązywania problemów alkoholowych nie jest wiążące dla osoby, której dotyczy, i nie może być w żaden sposób egzekwowane. Poddanie się badaniu zależy wyłącznie od woli skierowanego ${ }^{29}$. Przymusowe poddanie się badaniu przez biegłego może nastąpić jedynie na

22 Por. I. Skrzydło-Niżnik, G. Zalas, Ustawa o wychowaniu w trzeźwości i przeciwdziałaniu alkoholizmowi. Komentarz, doktryna, orzecznictwo, Kraków 2002, s. 371-372. Uchwała SN Izba Cywilna i Administracyjna z dnia 26 marca 1986 r., III CZP 72/85, OSNC 1986/12/191.

24 Por. art. 23 kodeksu cywilnego i art. 24 UoWwTiPA. Rozporządzenie Ministra Zdrowia z dnia 27 grudnia 2007 r. w sprawie biegłych w przedmiocie uzależnienia od alkoholu (Dz.U. 2007.250.1883 z późn. zm.).

26 Miejsce zamieszkania lub pobytu osoby, której postępowanie dotyczy.

27 Art. 25 UoWwTiPA

28 Art. 193 kodeksu postępowania karnego.

29 Por. wyrok Naczelnego Sądu Administracyjnego [dalej: NSA] w Warszawie z dnia 27 czerwca 2007 r., I OSK 323/07, LEX nr 339973. 
podstawie postanowienia prokuratora bądź zarządzenia właściwego sądu rejonowego. Listy biegłych orzekających w przedmiocie uzależnienia od alkoholu są prowadzone przez prezesów sądów okręgowych. Powołani biegli oprócz kwestii uzależnienia wypowiadają się o potrzebie terapii i wskazują rodzaj zakładu leczniczego (stacjonarny, otwarty).

Wniosek do komisji rozwiązywania problemów alkoholowych o skierowanie na badanie w przedmiocie uzależnienia może złożyć zarówno sama osoba zainteresowana, jak i inne uprawnione podmioty (krewny, członek rodziny, sąsiad itp.) lub instytucja (prokurator, policja, zakład pracy, opieka społeczna itp.).

O obowiązku poddania się leczeniu specjalistycznemu w zakładzie lecznictwa odwykowego orzeka właściwy miejscowo dla miejsca zamieszkania ${ }^{30}$ lub pobytu sąd rejonowy w postępowaniu nieprocesowym w składzie jednego sędziego, zgodnie z art. 509 kodeksu postępowania cywilnego [dalej: k.p.c.] ${ }^{31}$. Wydając postanowienie ${ }^{32}$ o przymusowym leczeniu odwykowym, sąd bada przede wszystkim, czy uczestnik postępowania faktycznie nadużywa alkoholu oraz czy ma to związek z określonymi w art. 24 ustawy o wychowaniu w trzeźwości i przeciwdziałaniu alkoholizmowi negatywnymi przesłankami. Obligatoryjne jest więc istnienie dwóch kumulatywnych przesłanek: pierwszej o charakterze medycznym - nadużywanie przez konkretną osobę alkoholu - oraz drugiej, którą literatura przedmiotu określa jako społeczną ${ }^{33}$ - określony w art. 24 ustawy jeden $z$ nagannych sposobów zachowania, który musi mieć związek z nadużywaniem

Zgodnie z treścią art. 25 kodeksu cywilnego przez miejsce zamieszkania należy rozumieć miejscowość, w której dana osoba przebywa z zamiarem stałego pobytu.

Art. 26 ust. 2 UoWwTiPA.

W celu zaznaczenia, że odnosi się ona nie do samego uzależnionego, lecz do mniejszej (rodzina) lub większej (np. sąsiedzi) społeczności. 
alkoholu ${ }^{34}$. Przesłanka społeczna zobowiązania do podjęcia obowiązkowego leczenia odwykowego powinna występować w dacie orzekania $^{35}$. Nie oznacza to jednak, że okresowe zaniechanie przez osobę uzależnioną od alkoholu jego spożywania bądź powstrzymanie się od negatywnych zachowań określonych w art. 24 ustawy z 1982 roku niweczy merytoryczną zasadność żądania orzeczenia obowiązku poddania się leczeniu odwykowemu ${ }^{36}$. Rozpoznając wniosek w tym przedmiocie, sąd ocenia, czy tego rodzaju zmiana w zachowaniu osoby, której wniosek dotyczy, ma charakter trwały czy tymczasowy w związku z toczącym się postępowaniem o obowiązek leczenia odwykowego. Przy ocenie sąd bierze pod uwagę zarówno okres zmiany zachowania, jak i jej motywy ${ }^{37}$. Wydane postanowienie wraz z uzasadnieniem doręcza się tylko stronie, która zgłosiła takie żądanie ${ }^{38}$.

Przedmiotowe postępowanie nieprocesowe, jak każde postępowanie jurysdykcyjne, jest postępowaniem wnioskowym. Ustawodawca w art. 26 ust. 3 określa podmioty, które mogą wystąpić do sądu $\mathrm{z}$ wnioskiem o orzeczenie wobec konkretnej osoby obowiązku poddania się leczeniu odwykowemu. Uprawnionym do złożenia tego wniosku jest gminna komisja rozwiązywania problemów alkoholowych oraz prokurator ${ }^{39}$. Wniosek złożony przez inne

Por. postanowienie SN z dnia 9 listopada 2007 r., V CSK 241/07, LEX nr 361289, OSNC-ZD 2009/1/1, Biul. SN 2008/3/8.

Postanowienie SN z dnia 9 listopada 2007 r., V CSK 241/07; Postanowienie SN z dnia 28 listopada 2012 r., III CSK 17/12., LEX nr 1293962.

Por. postanowienie SN z dnia 28 listopada 2012 r., III CSK 17/12.

Por. postanowienie SN z dnia 28 listopada 2012 r., III CSK 17/12.

Art. 357 k.p.c.

Formy i przesłanki udziału prokuratora w postępowaniu cywilnym uregulowane zostały $w$ art. 7 k.p.c., który przyznaje mu generalne uprawnienie do żądania wszczęcia postępowania w każdej sprawie albo wzięcia udziału w toczącym się już postępowaniu. Prokurator, podejmując decyzję o działaniu w sprawie cywilnej, kieruje się własną oceną, czy wymaga tego ochrona praworządności, praw obywa- 
podmioty sąd oddala $\mathrm{z}$ powodu braku legitymacji procesowej do wystąpienia z takim żądaniem. Zgodnie z dyspozycją $\$ 245$ Regulaminu urzędowania sądów powszechnych ${ }^{40}$ wniosek o wszczęcie postępowania złożony przez osobę nieuprawnioną przewodniczący wydziału przesyła prokuratorowi bądź gminnej komisji rozwiązywania problemów alkoholowych. Chociaż art. 26 nie wskazuje, jakie elementy powinien taki wniosek zawierać, musi on czynić zadość przepisom o pozwie ${ }^{41}$, a zatem - stosownie do wymogów art. 126 i 187 k.p.c. - zawierać: oznaczenie sądu, wnioskodawcy i uczestnika ${ }^{42}$, oznaczenie rodzaju pisma, osnowę wniosku, wskazanie dowodów na poparcie przytoczonych okoliczności, podpis składającego wnio$\operatorname{sek}^{43}$. Gminna komisja rozwiązywania problemów alkoholowych bądź prokurator do wniosku dołącza zgromadzoną dokumentację, w tym obligatoryjnie ${ }^{44}$ opinię biegłych (jeżeli zdołano ją uzyskać) ${ }^{45}$. Niedołączenie do wniosku opinii biegłego bądź brak wzmianki biegłego o okolicznościach uniemożliwiających jej wydanie stanowi

teli lub interesu społecznego. Na celowość udziału prokuratora w postępowaniu prowadzącym do nałożenia obowiązku leczenia w zakładzie lecznictwa odwykowego wskazał przekonująco Sąd Najwyższy w postanowieniu z dnia 9 października 2009 r., IV CSK 201/09, OSNC 2010/4/59.

Rozporządzenie Ministra Sprawiedliwości z dnia 23 lutego 2007 r. (Dz.U. 2007.38.249).

Osoby, wobec której ma być wydane orzeczenie o obowiązku poddania się leczeniu odwykowemu, przez podanie jej imienia, nazwiska, zawodu i miejsca zamieszkania.

W przypadku wniosku złożonego przez gminną komisję rozwiązywania problemów alkoholowych -zdaniem C. Zalas skoro przepisy ustawy nie regulują bliżej ustroju tych komisji, wniosek powinni podpisać wszyscy członkowie komisji, którzy uczestniczyli w podjęciu decyzji o skierowaniu do sądu wniosku (por. C. Zalas, Komentarz do art. 26 ustawy o wychowaniu w trzeźwości i przeciwdziałaniu alkoholizmowi, Lex Omega 48/2014).

44 Por. uchwała SN z dnia 11 września 2013 r., III CZP52/13, OSNC 2014/4/39, LEX nr 1371626, Biul. SN 2013/9/7. Art. 26 ust 3 UoWwTiPA. 
brak formalny podlegający uzupełnieniu na podstawie art. $130 \$ 1$ W Zw. $\mathrm{z}$ art. $13 \$ 2$ k.p.c. i art. 26 ust. 3 tej ustawy pod rygorem jego $z$ rrotu $^{46}$. Jeżeli brakuje opinii w przedmiocie uzależnienia, to sąd przed wyznaczeniem rozprawy ${ }^{47}$ zarządza przeprowadzenie ambulatoryjnego badania i sporządzenie opinii w przedmiocie uzależnienia uczestnika postępowania ${ }^{48}$. Sąd na podstawie art. 27 ust. 2 UoWwTiPA, jeżeli uzna to za niezbędne, na wniosek powołanych biegłych po wysłuchaniu uczestnika postępowania może zarządzić jego obserwację w zakładzie leczniczym przez okres do dwóch tygodni. Okres ten w wyjątkowych wypadkach na wniosek zakładu może być przedłużony do sześciu tygodni ${ }^{49}$.

Osoba, której postępowanie dotyczy, zobowiązana jest do poddania się badaniu (psychiatrycznemu i psychologicznemu oraz zabiegom niezbędnym do wykonania niezbędnych badań laboratoryjnych) i do zgłoszenia się do wskazanego zakładu leczniczego celem obserwacji ${ }^{50}$.

Zgodnie z postanowieniem Sądu Najwyższego z dnia 11 października 2001 roku postępowanie o zastosowanie przymusowego leczenia odwykowego należy do spraw z zakresu prawa osobowego w rozumieniu art. $519^{1} \$ 1$ k.p.c. ${ }^{51}$ Sąd orzeka o obowiązku poddania się leczeniu na rozprawie, która winna odbyć się w terminie jednego miesiąca od wpłynięcia wniosku ${ }^{52}$. O jej terminie zawiadamia się wnioskodawcę. Na rozprawie sąd wysłuchuje osobę zainteresowaną; może także wezwać wskazanych świadków oraz biegłych celem złożenia przez nich opinii uzupełniającej.

\footnotetext{
46 Por. uchwała SN z dnia 11 września 2013 r., III CZP 52/13.

$47 \S 246$ Regulaminu urzędowania sądów powszechnych (Dz.U. 2007.38.249).

48 Art. 27 ust. 1 UoWwTiPA.

49 Art. 27 ust. 2-3 UoWwTiPA.

50 Art. 28 ust. 1 UoWwTiPA.

51 Sygn. akt II CZ 100/01, LEX nr 52474, Biul. SN 2001/12/10.

52 Art. 29 UoWwTiPA.
} 
Jeżeli uczestnik postępowania nie stawi się na określone przez biegłych badanie we wskazanym zakładzie leczniczym, gdzie ma być przeprowadzona jego obserwacja, bądź nie stawi się na rozprawę, sąd może zarządzić jego przymusowe doprowadzenie przez policję $e^{53}$.

Wydane przez sąd prawomocne orzeczenie w przedmiocie leczenia odwykowego generuje obowiązek stawienia się w oznaczonym dniu we wskazanym zakładzie lecznictwa odwykowego w celu poddania się terapii. W przypadku uchylania się od tego obowiązku istnieje możliwość przymusowego doprowadzenia ${ }^{54}$.

Orzeczony przez sąd obowiązek poddania się przez osobę uzależnioną od alkoholu terapii w zakładzie lecznictwa odwykowego wygasa $\mathrm{z}$ upływem dwóch lat od chwili uprawomocnienia się postanowienia ${ }^{55}$, chyba że przed upływem tego terminu sąd zmienił postanowienie w zakresie rodzaju zakładu leczenia odwykowego albo orzekł o ustaniu tego obowiązku ${ }^{56}$.

Rodzaj zakładu leczenia odwykowego i długość terapii są zdeterminowane przez jej cel, jednak maksymalnie może ona trwać dwa lata od chwili uprawomocnienia się postanowienia o przymusowym leczeniu. Okres przymusowego leczenia odwykowego może być skrócony przez sąd na wniosek osoby zobowiązanej do leczenia, zakładu lecznictwa odwykowego, ustanowionego na czas trwania leczenia kuratora, prokuratora bądź z urzędu. Niezbędnym jest zasięgnięcie opinii zakładu prowadzącego terapię.

\section{Art. 30 ust. 1.}

Art. 32 ust. 1, 3 UoWwTiPA.

Również w wypadku, gdy cel leczenia w tym czasie nie został osiągnięty - por. uchwała SN z dnia 22 czerwca 1984 r., III CZP 17/84, OSNC 1984/12/208; uchwała SN Izba Cywilna i Administracyjna z dnia 26 marca 1986 r., III CZP 72/85, Lex Omega 3203, OSNC 1986/12/191.

Por. uchwała SN Izba Cywilna i Administracyjna z dnia 26 marca 1986 r., III CZP 72/85; art. 34 ust. 1, 2 i 4 w zw. z art. 24 i 26 ust. 1 i 2 ustawy z dnia 26 października 1982 r. o wychowaniu w trzeźwości i przeciwdziałaniu alkoholizmowi. 
W Polsce terapię osób uzależnionych od alkoholu prowadzi się $\mathrm{w}$ trybie stacjonarnym (zamkniętym) oraz niestacjonarnym (ambulatoryjnym) wyłącznie w publicznych bądź niepublicznych zakładach opieki zdrowotnej. Leczenie i terapia są w tym przypadku bezpłatne, również dla osób nieubezpieczonych ${ }^{57}$. Zasadniczą metodą leczenia uzależnienia w zakładach lecznictwa odwykowego jest psychoterapia uzależnienia, a postępowanie lecznicze ma wymiar wspomagający; jego cel stanowi głównie leczenie alkoholowych zespołów abstynencyjnych, farmakologiczne wsparcie psychoterapii, diagnostyka somatycznych szkód wynikających z nadużywania alkoholu oraz kwalifikowanie do leczenia specjalistycznego. System leczenia osób uzależnionych od alkoholu organizuje się odrębnie od systemu leczenia osób uzależnionych od innych substancji psychoaktywnych, choć w ramach obu systemów prowadzone jest też leczenie osób uzależnionych od kilku substancji (uzależnienie mieszane).

Osoby umieszczone w zakładach poprawczych i schroniskach dla nieletnich, u których stwierdzono uzależnienie od alkoholu, mają obowiązek poddania się zarządzonemu leczeniu odwykowemu. Decyzja w tym zakresie leży w gestii administracji zakładu lub schroniska. W stosunku do osoby małoletniego wymagana jest ponadto zgoda przedstawiciela ustawowego. W razie jej braku oraz w przypadku osoby pełnoletniej uzyskuje się zezwolenie sądu wykonującego orzeczenie, które winno poprzedzać zasięgnięcie opinii u biegłego o uzależnieniu i celowości terapii.

Leczenie odwykowe osób uzależnionych od alkoholu odbywających karę pozbawienia wolności nie jest zorganizowane w strukturze zakładów opieki zdrowotnej, lecz funkcjonuje w obrębie wydzielonych oddziałów terapeutycznych i nadzoruje je Wydział Penitencjarny Centralnego Zarządu Służby Więziennej. Oddziaływania terapeutyczne wobec skazanych uzależnionych od alkoholu 
prowadzone są najczęściej w trzymiesięcznych cyklach, obejmujących podstawowy program psychoterapii uzależnienia, takimi samymi metodami i środkami jak w pozawięziennych placówkach lecznictwa odwykowego.

b) w trybie ustawy Kodeks karny

Kodeks karny [dalej: k.k.] w art. $96 \$ 1$ daje możliwość sądowi, by skazując sprawcę na karę pozbawienia wolności (do lat dwóch) ${ }^{58}$ bez warunkowego zawieszenia jej wykonania za przestępstwo popełnione w związku z uzależnieniem od alkoholu, mógł wydać orzeczenie dotyczące umieszczenia sprawcy w zamkniętym zakładzie leczenia odwykowego (jeżeli zachodzi wysokie prawdopodobieństwo ponownego popełnienia przestępstwa związanego $\mathrm{z}$ uzależnieniem). Zastosowanie środka zabezpieczającego określonego w cytowanym paragrafie wymaga spełnienia proceduralnego obowiązku ujętego $\mathrm{w}$ art. 93 in fine k.k., tj. uprzedniego wysłuchania lekarzy psychiatrów oraz psychologa, albowiem art. 93 k.k. ma charakter normy gwarancyjnej w odniesieniu do wszystkich środków zabezpieczających, w tym umieszczenia w zamkniętym zakładzie lecznictwa odwykowego osoby skazanej na karę pozbawienia wolności za przestępstwo pozostające $\mathrm{w}$ związku $\mathrm{z}$ uzależnieniem ${ }^{59}$. Z góry nie orzeka się o czasie pobytu w zamkniętym zakładzie lecznictwa odwykowego, jednak minimalnie musi on wynosić trzy miesiące, a maksymalnie dwa lata. Zdaniem Magdaleny Kornak okres terapii

Art. $96 \S 2$ k.k.

Por. wyrok SN z 20 listopada 2013 r., III KK 409/13, LEX nr 1394092; wyrok SN z 13 listopada 2007, V KK 336/07, LEX nr 340577. Zaniechanie przez sąd wysłuchania biegłych psychiatrów i psychologa, a następnie orzeczenie o zastosowaniu środka zabezpieczającego przewidzianego w art. 96 § 1 k.k. stanowi zdaniem Sądu Najwyższego rażące naruszenie prawa (por. postanowienie z dnia 7 listopada 2007, V KK 318/07, LEX nr 332939). 
określony przez ustawodawcę jest racjonalny, ponieważ przed zastosowaniem względem uzależnionych sprawców środków represji karnej, mających na celu pozbawienie tych osób wolności, daje pierwszeństwo ich odpowiedniemu leczeniu, zmierzającemu do wyeliminowania zagrożeń wynikających $\mathrm{z}$ nałogu ${ }^{60}$. O zwolnieniu z zakładu orzeka sąd na postawie uzyskanej opinii przedmiotu prowadzącego leczenie, uwzględniającej wyniki terapii ${ }^{61}$. Ustawodawca dopuszcza też możliwość orzeczenia terapii w warunkach ambulatoryjnych w przypadku uzyskania postępów w leczeniu stacjonarnym, przy jednoczesnym poddaniu osoby uzależnionej w okresie próby ${ }^{62}$ pod nadzór

kuratora, osoby godnej zaufania, stowarzyszenia, instytucji albo organizacji społecznej, do której działalności należy troska o wychowanie, zapobieganie demoralizacji lub pomoc skazanym ${ }^{63}$.

Ustanowienie dozoru jest $\mathrm{w}$ świetle obowiązujących przepisów obligatoryjne. W orzecznictwie można spotkać pogląd, że zmiana formy leczenia na ambulatoryjną winna nastąpić dopiero po upływie minimalnego okresu pobytu w zakładzie zamkniętym, tj. po trzech miesiącach (co ma wynikać z brzmienia art. 96 k.k.) ${ }^{64}$. Zmiana formy zakładu leczniczego, w którym ma być odbywana terapia, nie wymaga zgody osoby zainteresowanej. Jeżeli osoba uzależniona uchyla się $\mathrm{w}$ okresie próby od poddania się terapii ${ }^{65}$ albo popełnia prze-

60 el. 2011.

61

62

63

64

65
M. Kornak, Glosa do postanowienia SN z dnia 21 lipca 2011 r., I KZP 9/11, Teza 3, LEX/ Art. 96 § 3 k.k.

Od 6 miesięcy do 2 lat.

Art. $97 \S 1$ k.k.

Z. Ćwiąkalski, Komentarz do art. 1-116 k.k., [w:] Kodeks karny. Część ogólna. Komentarz, t. 1, red. A. Zoll, Warszawa 2007, s. 1078.

Chodzi wyłącznie o takie sytuacje, gdy osoba zobowiązana do terapii swoim zachowaniem celowo zmierza do uniknięcia leczenia lub rehabilitacji; przesłanka 
stępstwo ${ }^{66}$ lub rażąco narusza porządek prawny ${ }^{67}$ bądź regulamin placówki leczniczej ${ }^{68}$, sąd na mocy art. $97 \$ 2$ k.k. może zarządzić jej umieszczenie w zamkniętym zakładzie lecznictwa odwykowego. Ponowne umieszczenie w zakładzie następuje na czas nieokreślony, gdyż nie można $\mathrm{z}$ góry określić okresu potrzebnego do wyleczenia danej osoby (znajduje tu zastosowanie reguła $\mathrm{z}$ art. $96 \$ 3$ k.k.), jednakże nie powinien on łącznie z pierwszym pobytem $\mathrm{w}$ takim zakładzie przekroczyć dwóch lat ${ }^{69}$.

Może się zdarzyć sytuacja, że sąd, orzekając o obowiązku poddania się uczestnika postępowania leczeniu odwykowemu, uzna, iż na skutek stwierdzonego uzależnienia zachodzi potrzeba jego całkowitego ubezwłasnowolnienia ${ }^{70}$. Powiadamia wówczas właściwego

ta nie dotyczy zatem przypadków, gdy unikanie leczenia lub terapii jest wynikiem zbiegu okoliczności, działania siły wyższej (np. choroby) czy też konieczności wypełniania takich obowiązków (zawodowych, rodzinnych itp.), które w danej sytuacji powinny być uznane za mające pierwszeństwo przed obowiązkiem poddania się leczeniu. Każde przestępstwo, bez względu na stopień jego ciężkości (zbrodnia, występek) czy formę podmiotową (umyślne, nieumyślne).

Nie chodzi tu o każde naruszenie porządku prawnego, ale tylko o takie, które w społecznym odczuciu uchodzi za wyjątkowo naganne, zatem takie, które godzi w dobra prawne uznane za szczególnie cenne bądź popełnione jest w szczególnie naganny sposób lub ze szczególnie nagannych pobudek, względnie sprawca narusza porządek prawny z dużą częstotliwością.

Nie każde naruszenie tego regulaminu, ale jedynie takie, które bezspornie charakteryzuje się odpowiednią skalą ciężkości. Nie musi to być jednak zachowanie wielokrotne (ustawa bowiem posługuje się liczbą pojedynczą - „naruszenie"), zatem wystarczy zachowanie jednorazowe, choć o znacznym stopniu dolegliwości (np. spowodowanie istotnego utrudnienia w funkcjonowaniu placówki czy wywołanie zgorszenia dla jej innych pacjentów). Co wynika z art. 96 § 3 k.k.

70 Zgodnie z treścią art. 13 kodeksu cywilnego osoba, która ukończyła 13 lat, może być ubezwłasnowolniona całkowicie, jeżeli wskutek choroby psychicznej, niedorozwoju umysłowego albo innego rodzaju zaburzeń psychicznych, w szczególności pijaństwa lub narkomanii, nie jest w stanie kierować swym postępowaniem. 
prokuratora, jeżeli nie brał on udziału w przedmiotowym postępowaniu. W razie orzeczenia przez sąd opiekuńczy ubezwłasnowolnienia określa on sposób sprawowania opieki oraz orzeka o umieszczeniu osoby w domu pomocy społecznej dla osób uzależnionych od alkoholu, chyba że zachodzi możliwość objęcia jej inną formą stałej opieki.

\section{c) Przymusowe leczenie odwykowe w trybie ustawy o ochronie zdrowia psychicznego}

Zgodnie z dyspozycją art. 21 ustawy o ochronie zdrowia psychicznego $^{71}$

osoba, której zachowanie wskazuje na to, że z powodu zaburzeń psychicznych może zagrażać bezpośrednio własnemu życiu lub zdrowiu lub życiu innych osób bądź nie jest zdolna do zaspokajania podstawowych potrzeb życiowych

może być poddana badaniu psychiatrycznemu ${ }^{72}$, przy czym nie jest wymagana jej zgoda ${ }^{73}$. Konieczność takiego badania leży w gestii lekarza psychiatry, a w przypadku braku możliwości jego udziału - innego lekarza ${ }^{74}$. Lekarz ten może zarządzić bezzwłoczne przewiezienie zbadanej osoby do szpitala, wskazując w sporządzonej dokumentacji medycznej okoliczności uzasadniające podjęcie takiej decyzji ${ }^{75}$. W tym

Dla ubezwłasnowolnionego całkowicie ustanawia się opiekę, chyba że pozostaje on jeszcze pod władzą rodzicielską.

71 Dz.U. 1994.111.535 z późn. zm.

72 Art. 21 §1 UoOZP.

73 Osoba małoletnia lub ubezwłasnowolniona całkowicie - bez zgody jej przedstawiciela ustawowego.

74 Art. 21 § 2 UoOZP.

75 Art. 21 § 3 UoOZP. 
przypadku możliwe jest też przyjęcie do szpitala bez zgody. Nadużywanie alkoholu może doprowadzić do choroby psychicznej lub zagrożenia zdrowia bądź życia zarówno osoby się tego dopuszczającej, jak i jej otoczenia. Dlatego w uzasadnionych przypadkach możliwe jest zastosowanie art. 21 cytowanej ustawy wobec nadużywających alkoholu.

Sprawy z ustawy z dnia 19 sierpnia 1994 roku o ochronie zdrowia psychicznego $^{76}$ należy zgodnie z postanowieniem Sądu Najwyższego z dnia 11 października 2001 roku zaliczyć do spraw z dziedziny prawa osobowego w rozumieniu art. $519^{1} \S 1$ k.p.c. ${ }^{77}$

\section{Zakończenie}

Ustawa z dnia 26 października 1982 roku o wychowaniu w trzeźwości i przeciwdziałaniu alkoholizmowi w zakresie leczenia odwykowego osób uzależnionych od alkoholu różni się od poprzednio obowiązującej ustawy z dnia 10 grudnia 1959 roku o zwalczaniu alkoholizmu (Dz.U. Nr 69 poz. 434). W szczególności ustawa z 1959 roku zajmowała się przymusowym leczeniem alkoholików w zakładach lecznictwa otwartego i zamkniętego, natomiast ta z 1982 roku przyjęła jako zasadę leczenia odwykowego dobrowolność terapii, stwarzając równocześnie warunki sprzyjające jej realizacji. Wielokrotnie podkreślane jest w literaturze przedmiotu, że podstawą takiego uregulowania ustawowego były założenia oparte na aktualnym stanie wiedzy i dotychczasowych doświadczeniach leczenia odwykowego, szczególnie iż dobrowolna terapia daje większe szanse jej skuteczności.

Przymusowe leczenie odwykowe jest wyjątkiem od przyjętej przez ustawodawcę zasady dobrowolności poddania się leczeniu

77 Sygn. akt II CZ 100/01, LEX nr 52474, Biul. SN 2001/12/10. 
odwykowemu przez osoby uzależnione od alkoholu. Celem sądowej instytucji przymusowego leczenia odwykowego osób nadużywających alkoholu jest motywowanie ich do podjęcia terapii uzależnienia. O skuteczności leczenia decyduje przede wszystkim jego dobrowolność, stąd w przypadku zastosowania przymusowej terapii jedną z kardynalnych przesłanek stanowi wyrobienie w osobie uzależnionej od alkoholu motywacji do leczenia. Stosowanie przepisów pozwalających na przymusowe leczenie osoby nadużywającej alkoholu winno następować z poszanowaniem konstytucyjnych gwarancji praw i wolności obywatelskich oraz odpowiednich norm prawa międzynarodowego, a ich interpretacja $\mathrm{z}$ uwzględnieniem zasady, że wszelkie ograniczenia praw i wolności nie mogą naruszać ich istoty. Podstawę prawną zobowiązania osób uzależnionych od alkoholu do leczenia odwykowego stanowią artykuły od 24 do 36 ustawy z dnia 26 października 1982 roku o wychowaniu w trzeźwości i przeciwdziałaniu alkoholizmowi. Izba Cywilna i Administracyjna Sądu Najwyższego w uchwale z dnia 26 marca 1986 roku (III CZP 72/85) stwierdziła, że

ingerencja w sferę wolności osobistej, oparta na orzeczeniu sądowym wydanym w trybie i na podstawie art. 26 i 29 ustawy o wychowaniu w trzeźwości, służy przede wszystkim dobru osoby uzależnionej od alkoholu, a dopiero pośrednio - dobru rodziny, środowiska, Narodu.

Natomiast w postanowieniu $\mathrm{z}$ dnia 28 listopada 2012 roku stwierdziła, iż

z punktu widzenia normatywnego stosowanie przymusowego leczenia osób uzależnionych od alkoholu leży przede wszystkim w interesie społecznym i ma służyć usunięciu zagrożenia ze strony takich osób w sferze życia rodzinnego i społecznego. Nie ma natomiast podstaw prawnych do umieszczenia osoby nadużywającej alkoholu 
w zakładzie lecznictwa odwykowego wyłącznie przez wzgląd na jej interes $^{78}$.

Chociaż do przyjęcia zgłoszenia i wszczęcia postępowania zobowiązana jest gminna komisja rozwiązywania problemów alkoholowych, właściwa dla miejsca zamieszkania lub pobytu osoby, której dotyczy postępowanie, o obowiązku przymusowego leczenia musi bezwzględnie orzec sąd. Uprawnień tego rodzaju nie posiada żaden inny organ, a w szczególności organ administracji publicznej, samorządowej lub rządowej. Złożenie do sądu wniosku o przymusowe leczenie jest wyrazem realizacji przez organ władzy publicznej uprawnienia do wszczęcia postępowania $\mathrm{z}$ zakresu prawa osobowego w trybie postępowania cywilnego przed sądem powszechnym i zdaniem jurysprudencji nie wywołuje jakichkolwiek zmian w sferze uprawnień lub obowiązków podmiotu, którego dotyczy ${ }^{79}$. Wynikiem postępowania nieprocesowego jest decyzja o konieczności orzeczenia o obowiązku poddania się danej osoby przymusowemu leczeniu odwykowemu. W toku postępowania sąd bada przede wszystkim, czy osoba, która ma być zobowiązana do leczenia, faktycznie nadużywa alkoholu oraz czy nadużywanie przez nią tej substancji stanowi powód pojawienia się zjawisk wymienionych w ustawie o wychowaniu w trzeźwości i przeciwdziałaniu alkoholizmowi, które muszą wystąpić,

Postanowienie SN z dnia 28 listopada 2012 r., III CSK 17/12, LEX nr 1293962. Por. postanowienie SN z dnia 9 listopada 2007 r., V CSK 241/07, OSNC-ZD 2009/1/1; uzasadnienie wyroku Trybunału Konstytucyjnego z dnia 4 lipca 2006 r., III CRN 43/05, OTK-A 2006/7/78 oraz uzasadnienie postanowienia SN z dnia 4 października 1972 r., III CRN 222/72, OSPiKA 1973/11/220, wydanego na gruncie art. 13 poprzednio obowiązującej ustawy z dnia 10 grudnia 1959 r. o zwalczaniu alkoholizmu (Dz.U.1959.69.434, z późn. zm.), będącego odpowiednikiem art. 24 UoWwTiPA. Por. wyrok NSA w Warszawie z dnia 27 czerwca 2007 r., I OSK 323/07, LEX nr 339973. 
aby sąd mógł orzec o jej obowiązku poddania się leczeniu odwykowemu. Ustawowa zasada dobrowolności leczenia odwykowego ogranicza sąd w orzeczeniu obowiązku leczenia przymusowego w przypadku, gdy stwierdzi, iż wprawdzie dana osoba nadużywa alkoholu i równocześnie np. uchyla się od pracy lub zakłóca spokój i porządek publiczny, ale takie zachowania nie wykazują związku $\mathrm{z}$ nadmiernym spożywaniem tej substancji. Zobowiązanie nie ma charakteru przymusu prawnego. Przymus stosowany jest na etapie doprowadzenia osoby uzależnionej od alkoholu na badanie przez biegłych, na rozprawę w sądzie i do zakładu leczniczego na podjęcie terapii, jeżeli odmawia ona współpracy. Nie ma jednak możliwości prawnych ani organizacyjnych zatrzymania pacjenta w zakładzie lecznictwa odwykowego wbrew jego woli (jeżeli nie prezentuje on objawów choroby psychicznej i nie zagraża własnemu zdrowiu i życiu bądź życiu innych osób). Sąd decyduje również, w jakiego rodzaju zakładzie lecznictwa odwykowego (stacjonarnym bądź niestacjonarnym) ma odbywać się terapia.

Ponieważ zgodnie z przepisem art. 26 UoWWTiPA o zastosowaniu obowiązku poddania się terapii w zakładzie lecznictwa odwykowego sąd orzeka w postępowaniu nieprocesowym, stosuje on przepisy kodeksu postępowania cywilnego, dotyczące postępowania nieprocesowego $\mathrm{w}$ zakresie, $\mathrm{w}$ jakim postępowanie to nie zostało uregulowane w cytowanej ustawie. A zatem w sprawach proceduralnych nieuregulowanych przepisami omawianej ustawy należy kierować się przede wszystkim przepisami części pierwszej księgi drugiej tytułu I, tj. art. od 506 do 525 k.p.c.

Należy stwierdzić, iż przymusowe leczenie odwykowe nie jest sprzeczne $\mathrm{z}$ art. 5 ust. 1 lit. e Konwencji o ochronie praw człowieka i podstawowych wolności (Dz.U. z 1993 r. Nr 61 poz. 284 z późn. zm.), która dopuszcza zgodne z ustawą pozbawienie alkoholika wolności. 